\title{
Drama Show as a Means of Social Work Intervention to Develop the Self-esteem and Career Achievement of Secondary School Students in Macau
}

\author{
Jayson Chi Kin Lou, Siu Fung Chung* \\ Kiang Wu Nursing College of Macau, Est. Repouso No. 35, R/C, Macau SAR, PR China
}

\begin{abstract}
Background: While Macau is among the richest regions in the world, its young people who do not have sufficient social resources usually lack visions in their career choices because the economy of the city relies heavily on gaming and tourism. This paper presents a case to show how a social work intervention group has developed the self-esteem of a group of underperforming secondary school students in Macau, which has in turn affected some of the students' career achievements a decade later. Methodology: A drama show is used as the means of this social work intervention and the generalist model of social work practice is used to guide the process. The input of the social worker and the reaction of the students during various phases of the project are presented. Results: The changes in self-esteem of the students in the short term and career achievements in the long term have been observed, and positive effects are detected. Reflections: To benefit the development of a youth group, it is important to understand what the target group needs. Drama show is a useful tool to meet their need in life development and a way to enhance their social functioning. The social worker's professionalism fails if the group members made a good show but demonstrated no improvement in life development.
\end{abstract}

Keywords Macau, Social Work Intervention, Secondary Students, Self-esteem, Career Achievement

\section{Introduction}

\section{The Trigger of This Paper}

The rapid development in the internet has made it much easier to connect people, no matter how long they have lost contact. Because of the Facebook, I have reconnected a group of students who I worked with when I started my field work placement in social work in a secondary school in 2004. Through joining the wedding activities of one of the students in 2016 incidentally, I have had a chance to talk to them. I am pleased to know what they have achieved in their lives. Different from the time when I knew them as a group of underperforming students with low self-esteem, most of them are now having good achievement in their careers and personal lives. While my use of drama show as a social work intervention for them cannot be proved as causal, I would consider it an important simulator of their positive developments.

\section{Drama as an Intervention for Youth Development}

Dramas have been used as intervention tools for school students' development in all age groups and in many countries (Abbs, 2013; Gay \& Hanley, 1999; Gibson, 2015; Wallewein, 1994). These dramas are often arranged by teachers with or without the input of performers, and with or without performance shows of the dramas.

Social workers often set up psychodrama groups as therapeutic tools and no performance shows are arranged although drama show has been used as a tool of social work intervention for school leavers in community settings (Kemp, 2006).However, no report on the adoption of drama show for such purpose can be found in the literature. Therefore, we consider this project to be innovative and worth sharing with the social work community internationally.

\section{Macau}

Macau, also spelled Macao, is a Special Administrative Region of the People's Republic of China. Macau is well-known for, and probably is well-known only for its gambling industry. Its gaming revenue has been the world's largest since 2006 (Barboza, 2007). Macau is among the richest regions and its GNP per capita in 2016 was the highest in the world, according to the World Bank 
(The World Bank, n.d.). Despite its wealth, the subjective well-being of Macau people is not high. (No study on Macau's subjective well-being in comparison with other nations has published in the English language. As most studies on this topic report similar subjective well-being between Macau and Hong Kong, the other special administrative region of the People's Republic of China, and Hong Kong is around the middle (72 among 156 regions) on World Happiness index (Helliwell, Layard, \& Sachs, 2017). With the economy heavily dependent on gaming and tourism, young people in Macau usually lack a vision on career choice other than the predominant industry, especially among those young people who do not have many social resources.

\section{Background of the Intervention Project}

In 2004, when I, the first author, was a social worker student, I started my field work placement in a secondary school in Macau. Most students of this school came from lower class families. I found that a group of students (about ten individuals aged 13-17) were experiencing low self-esteem, and they were treated in a way for those who could not have much progress at school. Most of them did not gain acceptance of teachers in the form of praises. At the same time, when I talked to them, it seemed that they also treated themselves as what they had been defined at school. Furthermore, as many youths in Macau were destined by their family traditions to join the gaming industry once they reached the minimum age requirement at 18 , some of them thought that they had to leave school and started working in casinos at the age of 18 . They could not think of other career plans.

Not wanting them to go on like that, I planned to help them change their mindset from negative into positive.

\section{Setting up the Theoretical Grounds for the Intervention}

Revision on the basic missions

Being a social worker, we need to bear in mind our three missions:

a. problem solving;

b. enhancing social functions; and

c. advocating social justice.

Hence, from the first day I began my practicum, I always remind myself of my function in the organization.

The Search for theoretical grounds

When I started to think about the needs of the students, I considered what the best way to help them was. The text books taught me the theories and knowledge about the needs of students, but at the same time, my instructor always told the facts that were not mentioned in the books.

Before I started a group for my work in the organization as a professional social worker, I followed the common practice to prove that what I was doing was a serious task in the professional field of social work. Therefore, I read about theories of youth development.

\section{a. Maslow: Hierarchy of Need}

Maslow's hierarchy of need listed the seven needs of human beings, namely physiological, safety, social, esteem, cognitive, aesthetic and self-actualization needs. (Nolen-Hoeksema, 2014)

In the basic analysis of the theory, I thought that the details mentioned in esteem need could describe what the students needed, that is, they needed some experience to prove their value. In this situation, they could not fulfill their needs, both from the school and themselves.

\section{b. E. Eriksson: About Life Development Mission}

Eriksson's life span development theory also mentions that the youth from 13-20 need to get success in self-identification. They need to get well prepared before turning to adult, both in confidence and experience of success. (Baltes and Schaie, 2013)

If they needed to build up their identity well, they had to keep a positive attitude to plan for their growth and try to learn from their experience so as to get success in their life development.

\section{c. Principal of Social Work: Individualization}

Among the seven principles of social work, I always emphasized the importance of individualization. Having read books about the youth, I knew that general group experience was not sufficient for their individual growth.

\section{Choosing the Intervention Model}

There were various social work intervention models but I considered the generalist model of social work practice the most suitable one for me to apply. This model is a seven-step process in the order of: 1 . engagement; 2 . assessment; 3 . planning; 4. implementation; 5 . evaluation; 6. termination; and 7. follow-up. (Kirst-Ashman and Hull, 2016).

\section{Methodology and Results}

Guided by the generalist model of social work practice, I carried out the project step-by step.

\section{Engagement}

I set three criteria for my recruitment of members. They should not:

a. have performing experience on stage;

b. be a committee member in the volunteer group;

c. be selected by the teachers.

After setting my recruitment target, I went down to the 
basketball court and the pantry at the recess time to talk to the students about my idea so that I could start my group design.

\section{Assessment: Their Needs versus the Underlying Problems}

They were youth in the school who would like to have a chance as other students in other schools in Macau. However, they thought that they came from the lower classes in the society. They also thought that the school would not allow them to perform on the stage. They were frustrated by these ideas so that they were in a low self-esteem. Hence, they merely kept what they wanted in their mind.

After my analysis, I thought that a self-esteem enhancing group would be a realistic selection and a form of developmental group would be suitable.

\section{Planning: Designing a Group by Using Intervention Theories}

What should I prepare for them? I pondered for a long time about what was important for making significant changes within a group. Therefore, I read the Systems Theory which mentions about the importance of interaction within the life system. It gave me a hint that if I wanted to make impact in the group, I could try to do something for them within their life system. Eventually I chose to let them make achievement in the school.

The theory of social learning from Bandura (Bandura, 1977) provided me a scenario about what I should do in order to help them.

About the social learning progress, Bandura mentions that human being can learn from observing, sharing and personal experience. After receiving messages from stimulations, human beings would start to decode these messages and combine the information to their knowledge. When they face a similar scenario next time, this new experience will reflect on how they overcome the challenge. Finally, if they can solve the problem, the success experience will be stored as their own resources.

For further knowledge, as human beings get a positive experience, it will allow them to get better every time they finish the mission. That is a self-efficacy process.

Therefore, I started the group with the task of preparing a Christmas night show as the progress goal. I hoped to enhance their self-esteem from that so as to give them a positive experience.

\section{Forming of predictions and expected outcomes}

After getting information from them and from literature, I expected that in the progress before finishing the drama show:

a. most of the members would turn from a passive thinking mode to a more positive one;

b. they could rebuilding their self-identity with a higher self-esteem; and

c. the group cohesion would be enhanced to a stable level.

I also formulated predictions and expected outcome of various phases as stated in Table 1.

Table 1. Predictions and expected outcomes of various phases

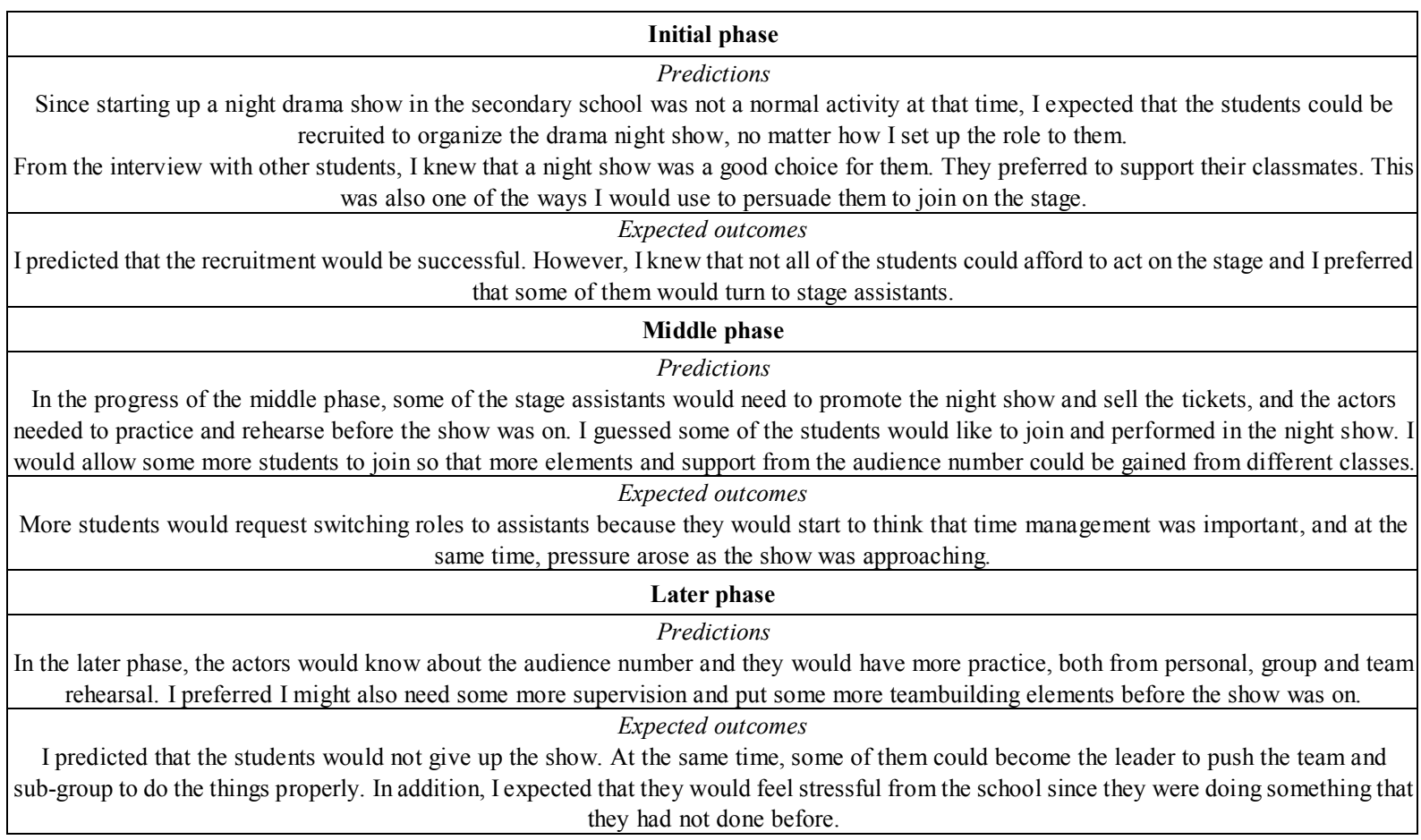




\section{Implementation}

According to my planning, the show would be held in late December, so I started to interview different students in the middle of September and set up the recruitment in the middle of October. The different roles would be allocated in late October and so the preparation work would start. The progress of group dynamics is listed in Table 2.

Table 2. The progress of group dynamics

\begin{tabular}{|c|c|c|c|}
\hline Time & Stages & My input & Student's reaction \\
\hline & Initial phase & & \\
\hline Late September & $\begin{array}{l}\text { Interview and } \\
\text { unofficial } \\
\text { promotion }\end{array}$ & $\begin{array}{l}\text { I interviewed different students to collect ideas } \\
\text { about having a night show in the school. At the } \\
\text { same time, I told them they could have a chance } \\
\text { to perform on the stage and let other students } \\
\text { know they had the ability to make a good show. }\end{array}$ & $\begin{array}{l}\text { Most of the students were surprised about } \\
\text { having a show at school. They would like to } \\
\text { be volunteer workers or the actors. At least } \\
\text { they wanted to be the audience. } \\
\text { I had full confidence that the show would be } \\
\text { successful. }\end{array}$ \\
\hline \multirow[t]{3}{*}{ Mid October } & $\begin{array}{l}\text { Recruitment and } \\
\text { division of labour }\end{array}$ & $\begin{array}{l}\text { During the recruitment, I visited different } \\
\text { classes during the recess time, allowing them to } \\
\text { apply and join the show. } \\
\text { I encouraged the students that life could be } \\
\text { controlled in their hand if they tried hard. }\end{array}$ & $\begin{array}{l}\text { More than } 50 \text { students joined my drama } \\
\text { performance program. } \\
15 \text { of them wanted to be assistants while } 35 \\
\text { of them would like to get on the stage as } \\
\text { performers. }\end{array}$ \\
\hline & $\begin{array}{l}\text { Conclusion of } \\
\text { initial stage }\end{array}$ & $\begin{array}{l}\text { The recruitment was successful. } \\
\text { The students went directly to division of labour. } \\
\text { The group contribution was more stable than I e } \\
\text { The reaction from the students was more active } \\
\text { The show was favorable to them. }\end{array}$ & $\begin{array}{l}\text { pected } \\
\text { han I expected. }\end{array}$ \\
\hline & Middle stage & My input & Student's reaction \\
\hline \multirow[t]{3}{*}{$\begin{array}{l}\text { Mid to late } \\
\text { October }\end{array}$} & Sale of tickets & $\begin{array}{l}\text { I told them to design the tickets by themselves. I } \\
\text { also asked them to invite the teachers to join the } \\
\text { show by giving them free tickets near the time } \\
\text { of the show. }\end{array}$ & $\begin{array}{l}\text { The tickets were sold out on the first day and } \\
\text { the assistant group got great encouragement } \\
\text { from the classmates. Some more students } \\
\text { would like to join the group to see how they } \\
\text { could help in the big show. } \\
\text { At the same time, more than } 10 \text { teachers } \\
\text { would like to join the show and the students } \\
\text { were delighted with the support. They got } \\
\text { more active to make the show a success. }\end{array}$ \\
\hline & $\begin{array}{l}\text { Adding elements } \\
\text { to the show }\end{array}$ & $\begin{array}{l}\text { In the former stage I asked the students about } \\
\text { their willingness to join the show as an actor or } \\
\text { performer. I went to the classroom to ask them } \\
\text { again about their final decision. }\end{array}$ & $\begin{array}{l}\text { Other than the } 35 \text { actors, } 4 \text { groups of students } \\
\text { from different classes wanted to perform on } \\
\text { the show. For all of them, it would be their } \\
\text { first appearance in a show. }\end{array}$ \\
\hline & $\begin{array}{l}\text { Organizing the } \\
\text { show }\end{array}$ & $\begin{array}{l}\text { As this was the most important part of the show, } \\
\text { I spent much time to decide the division of } \\
\text { labour according to the different personality of } \\
\text { the students, and also what they could gain from } \\
\text { the experience. }\end{array}$ & $\begin{array}{l}\text { At the beginning of the drama rehearsal and } \\
\text { training program, } 8 \text { of them shifted back to } \\
\text { the assistant group and finally the team } \\
\text { became a group with } 27 \text { actors, which was } \\
\text { the same as I expected. The remaining actors } \\
\text { felt positive. }\end{array}$ \\
\hline $\begin{array}{c}\text { Late November } \\
\text { to early } \\
\text { December } \\
\end{array}$ & Later phase & My input & Student's reaction \\
\hline \multicolumn{4}{|c|}{$\begin{array}{l}\text { Through encouraging the students to have more participation in the drama show, I regarded it as the tool to enhance their cohesion and } \\
\text { self-esteem. Here is what I did in the group development. }\end{array}$} \\
\hline $\begin{array}{l}\text { a. } W r i \\
\mathrm{~V} \\
\text { que } \\
\text { " } W \\
\text { "W } \\
\text { "W } \\
\text { The } \\
\text { " } W \\
\text { "W } \\
\text { "W } \\
\mathrm{v}\end{array}$ & $\begin{array}{l}\text { ng the script } \\
\text { hen I organized the } 2 \\
\text { ions to them to let th } \\
\text { at would you want to } \\
\text { at do you want to tell } \\
\text { at do your classmate. } \\
\text { replies were simple } \\
\text { want a Christmas po } \\
\text { want to eat snacks o } \\
\text { want to enjoy a part. } \\
\text { hen concluding their }\end{array}$ & $\begin{array}{l}\text { actors, I knew that none of them had any experien } \\
\text { m enjoy the process from the very beginning. } \\
\text { lo in school legally but you are not allowed to do } \\
\text { he teachers about what you think?" } \\
\text { expect to feel good when you tell them something? } \\
\text { ut positive. } \\
\text { ty." } \\
\text { stages." } \\
\text { with no boundaries." } \\
\text { ishes, I wrote a script with the background of Chr }\end{array}$ & $\begin{array}{l}\text { in performing on the stage. Hence I put some } \\
\text { ??" } \\
\text { stmas party. I promised they could do what the }\end{array}$ \\
\hline
\end{tabular}




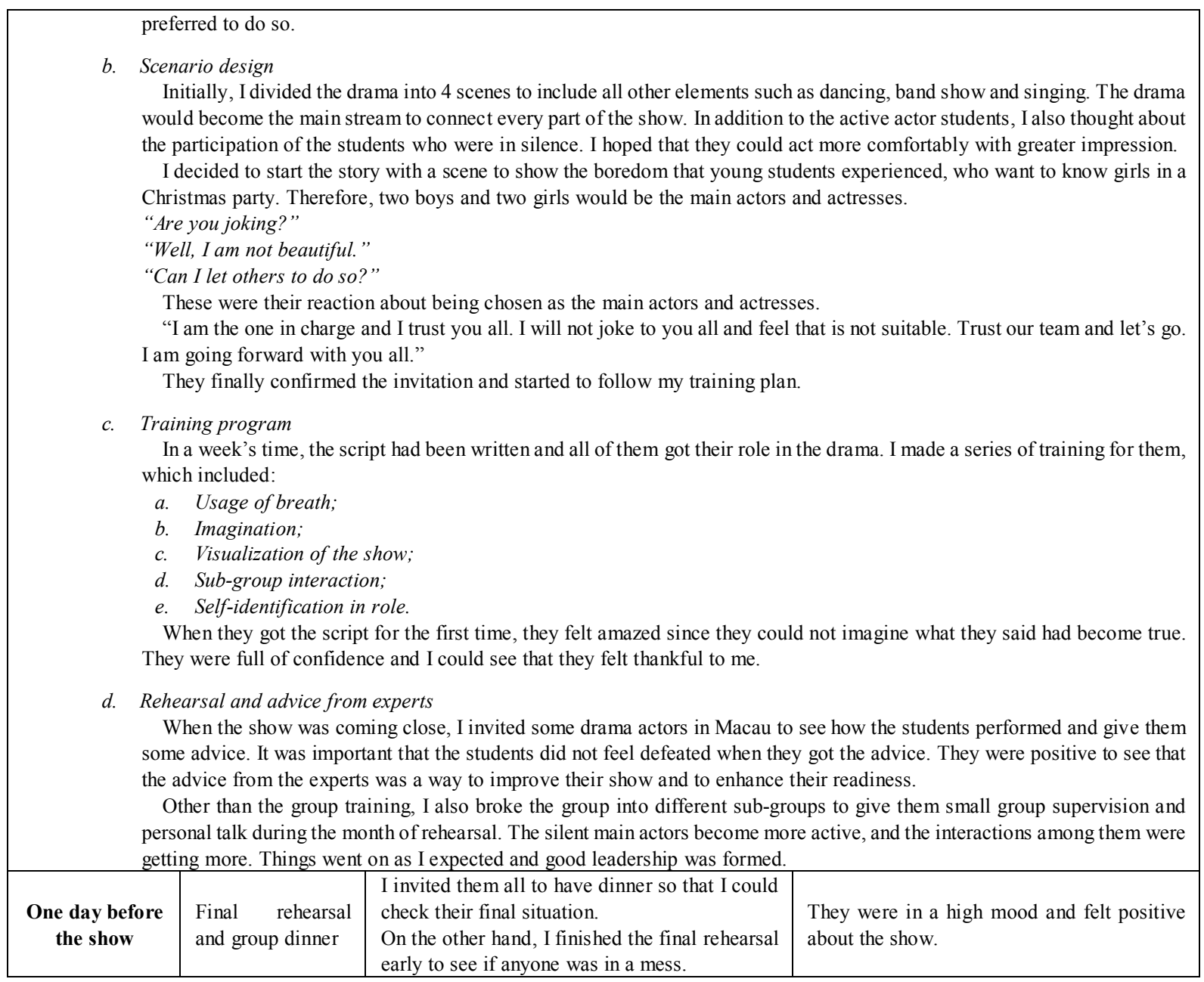

\section{Evaluation}

More than 250 audiences joined the show, including the principal, 20 teachers and staff, and more than 200 students. The show was successful and the students really enjoyed having a show like that. They could do what they wanted on the stage, such as having snack, dancing around or playing games, which I had set up as part of the drama, and they played in the drama as they wanted.

\section{Conclusion Session}

After the show, I called up a conclusion session at the meeting so as to let them summarize what they had learnt. Most of them were glad about the show and felt that they would have a bright future. Although there were differences in their age, they showed the power to overcome the challenges. Some of them even sang around after finishing the show that they were not afraid to face other people.

\section{Termination}

Soon after the group finished the show, I also finished my practical field work.

\section{Follow-up}

\section{My Predictions and Expected Outcomes}

After three months' time, they called up for a gathering in Easter. Most of them came and talked about their future plan. I could see that all of them could confirm at least their mindset, and some even went out of my expectation. For example, the most silent student would like to have further study in education to become a teacher in the future.

Therefore, the three tasks of my development group were successful, which was evidenced by:

a. Most of the members turned from a passive thinking mode to a more positive one;

b. They were rebuilding their self-identity with a higher self-esteem;

c. The group cohesion was enhanced to a stable level.

\section{Their Career Achievements}

At present, more than a decade after the drama show, two of the students are working as news reporters, one as a kindergarten teacher, two as social workers, and one as a columnist. The others have also found their career pathway to live with self-esteem. 


\section{Reflection}

Before starting to plan for a developmental group, the most important consideration is "the need of my target group". It is easy to start up a group but not necessarily a successful one. Different theories tell professionals what the core values are and there are always some structures we can learn from and know about. Nonetheless, it is essential to know that while theories can be used to support our ideas for segmentation and filtering, direct communication is the key to identifying their genuine needs. The group design has to be based on theories on good segmentation and carried out with logical thinking.

As for what to do in the group and what can be done, it depends very much on how much the worker knows about the target. I had many interviews with the students to understand what they needed and wanted, as well as how most of the students preferred to get them. The more the worker can gain the students' trust and respect, the better group performance can be done. More reflection on the experience accumulated can help workers know more about the impact of their work on the students.

Before assuming the students' behavior or reaction in the group, the worker should consider their strengths and weaknesses, the group members' characteristics and the chances of success in achieving the goal. In the drama group, I knew that I could communicate with the students well. Therefore I firstly set out to identify what they wanted. However, as I was only a practicing social worker in placement at the school with its own regulations, my position in the power alignment was not strong. I had to do more to persuade the school administrators to think positively by telling them what our group would do. After finishing the first step, which was the preparation work, I found that a Christmas party was a great chance for everyone to come together with a common purpose. Hence I took the opportunity to plan for a Christmas in December so that I could have three months to prepare for it. I thought much about what might happen, the pros and cons, as well as viable solutions. I also considered the stressor that the group might face, such as how to face the classmates and teachers on the stage, and how the school might think about the contents of the drama in that situation. It was a process of SWOT analysis in making assumptions.

Finally, I pre-visualized the situation in my mindset and jotted down what might happen in the entire process, from the initial phase to the final phase. As a worker, I had to get well prepared for the possible outcomes in my predictions before the operation started. I predicted the environment and actions that might take place on the stage, such as what would happen to them and how they could overcome the problems. At the same time, I should promote group cohesion among the students for their development through the activity. Hence I also predicted what might happen in the group and how to let them grow up in the entire process.
The use of creating scenarios, from the outermost circle to the inner part of the members, was an important part to reduce the possibility of crises and could also expand the creativity of the group members and allow them to enjoy the process through sorting out the problems arising.

As a social worker, and not a director of a drama, I need not have created the dramatic show for the members and the audience. But I staged it because I knew that no matter how the performance might be done, and it might not proceed as expected, the members could still develop and grow in the group during the various stages of the drama show.

In conclusion, I think the drama development group is just a tool to provide the members with the elements they need in their life development, and a way to enhance their social functioning. The career developments of the members who I have recently met after ten years of the performance may be regarded as evidence to support my idea that drama show is a good tool for social work intervention. My role as a social worker would have failed if the group members staged a good drama show only but made no improvement in their life development.

\section{Acknowledgements}

We express our sincere thanks to the students who participated in the group and shared with us their experience in career development.

\section{REFERENCES}

Abbs, S. (2013). Drama in education to shape the critical capacities of young people. Harvard Educational Review, 83(1): p62-64.

Baltes, P. B. \& Schaie, K. W. (Eds.). (2013). Life-span developmental psychology: Personality and socialization. Elsevier.

Bandura, A. (1977). Social learning theory. New York: General Learning Press.

Barboza, David (23 January 2007). Macao Surpasses Las Vegas as Gambling Center. The New York Times.

Gay, G. \& Hanley, M. S. (1999). Multicultural empowerment in middle school social studies through drama pedagogy. The Clearing House: A Journal of Educational Strategies, Issues and Ideas, 72(6): 364-70.

Gibson, R. (2015). The school drama program: delivering process drama via a teaching artist. Drama Australia Journal, 39(1): 76-95.

Helliwell, J., Layard, R., \& Sachs, J. (2017). World happiness report 2017, New York: Sustainable Development Solutions Network. 
Vol.6. No.2 Jun, 2018, pp. 23-29

Kemp, M. (2006). Promoting the health and wellbeing of young black men using community-based drama. Health Education, 106(3): 186-200.

Kirst-Ashman, K. K. \& Hull, G. H. (2016). Empowerment Series: Understanding Generalist Practice. Boston, MA: Cengage Learning,

Nolen-Hoeksema, S., Fredrickson, B. L., Loftus, G. L. \& Lutz, C. (2014). Atkinson \& Hilgard's Introduction to Psychology (16th ed.). Boston, MA: Cengage Learning.

The World Bank (n.d).

https://data.worldbank.org/indicator/NY.GNP.PCAP.CD?locatio ns $=$ MO, Retrieved 14 January 2018.

Wallewein, D. (1994). "Collective Creation": A multidisciplinary drama program. The Clearing House: A Journal of Educational Strategies, Issues and Ideas, 67(6): 345-347. 